\title{
EGFR NM_005228.3:c.2239_2253del15
}

National Cancer Institute

\section{Source}

National Cancer Institute. EGFR NM 005228.3:C.2239 2253de/15. NCI Thesaurus. Code C98562.

A deletion of 15 nucleotides from the coding sequence of the EGFR gene from position 2239 through 2253. 